\title{
Consequence Analysis of a Hypothetical Contained Criticality Accident in the Hanford Critical Mass Laboratory
}
B. F. Gore
D. L. Strenge
J. Mishima

December 1984

Prepared for the U.S. Department of Energy under Contract DE-AC06-76RLO 1830

Pacific Northwest Laboratory Operated for the U.S. Department of Energy by Battelle Memorial Institute 


\title{
DISCLAIMER
}

This report was prepared as an account of work sponsored by an agency of the United States Government. Neither the United States Government nor any agency thereof, nor any of their employees, makes any warranty, express or implied, or assumes any legal liability or responsibility for the accuracy, completeness, or usefulness of any information, apparatus, product, or process disclosed, or represents that its use would not infringe privately owned rights. Reference herein to any specific commercial product, process, or service by trade name, trademark, manufacturer, or otherwise, does not necessarily constitute or imply its endorsement, recommendation, or favoring by the United States Government or any agency thereof. The views and opinions of authors expressed herein do not necessarily state or reflect those of the United States Government or any agency thereof.

\author{
PACIFIC NORTHWEST LABORATORY \\ operated by \\ BATTELLE \\ for the \\ UNITED STATES DEPARTMENT OF ENERGY \\ under Contract DE-AC06-76RLO 1830
}

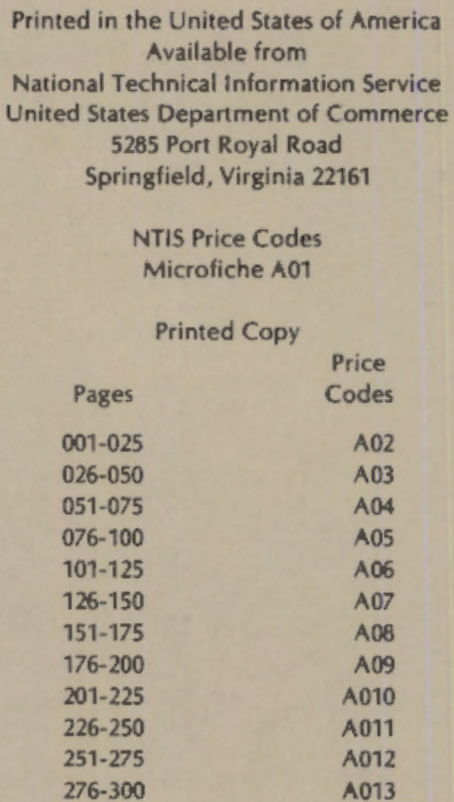


CONSEQUENCE ANALYSIS OF A HYPOTHETICAL CDNTAINED CRITICALITY ACCIDENT IN THE HANDORD CRITICAL MASS LABORATORY
B. F. Gore
D. L. Strenge
J. Mishima

December 1984

Prepared for the U. S. Department of Energy under Contract DE-AC06-76RLO 1830

Pacific Northwest Laboratory Richland, Washington 99352 

The original hazards summary report (i.e., SAR) for the CML addressed the consequences of a hypothetical accidental critical excursion occurring with the experimental assembly room open. That report indicated that the public would receive insignificant radiation exposure regardless of the type of atmospheric condition, while plant personnel could possibly receive exposures greater than the annual exposure limits for radiation workers, when a strong inversion existed.

This present analysis investigates the consequences of a hypothetical accidental criticality occurring with the room sealed. This is the far more likely condition to be encountered. Due to the containment capabilities designed and built into the critical assembly room, the consequences are greatly reduced below those presented in HW-66266. Despite the incorporation of many extremely conservative assumptions to simplify the analysis, the radiation doses predicted for personnel 100 meters or more distant from the $\mathrm{CML}$ are found to be smaller than the annual radiation dose limit(1) for members of the public in uncontrolled areas during routine, nonaccident operations. Therefore, the results of this analysis demonstrate that the occurrence of a hypothetical critical excursion within the sealed experimental assembly room at the Hanford Critical Mass Laboratory presents only a small, acceptable risk to personnel and facilities in the area and no additional safety systems or controls are needed for the continued safe operation of the CML. The nature of the work at the laboratory has not significantly changed from that covered by the current SARs; thus no updating of these reports is needed at this time. 



\section{CONTENTS}

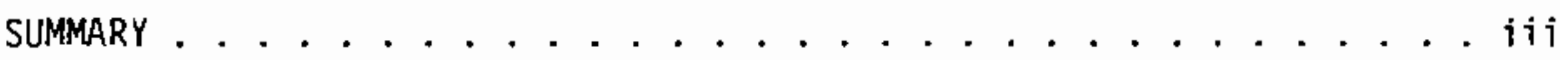

INTRODUCTION . . . . . . . . . . . . . . . . . . . . 1

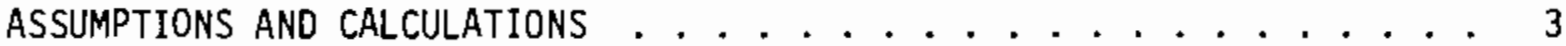

Magnitude of the Critical Excursion . . . . . . . . . . 3

Production and 0ispersion of Fission Products and Plutonium . . . 3

Pressurization and Leakage from the Room . . . . . . . . . . . 4

Plate-Out of Radioactivity ................ . . 5

Meteorological Conditions . . . . . . . . . . . . . 5

Continued Presence of Personnel . . . . . . . . . . . . . 7

Calculational Methods .................. . 7

RESULTS ANO CONCLUSIONS . . . . . . . . . . . . . . . . . . 9

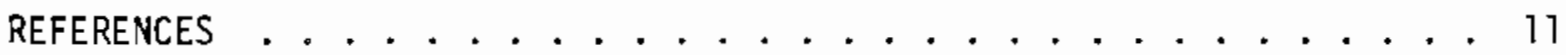

DISTRIBUTION . . . . . . . . . . . . . . . . . . . 12 

INTRODUCTION

The original SAR for the Critical Mass Laboratory (CML), (2) HW-66266, did not address the effects of a criticality accident with the experimental assembly room sealed. It did, however, address the effects of an accident occurring with the room open, with the ad hoc assumption that ten percent of the gross fission productions resulting from the excursion were released from the building. Downwind doses at locations of built-up areas (Purex $\sim 3000 \mathrm{ft}$. $\mathrm{SE}$; power house $\sim 3000 \mathrm{ft}$. SW) were low except for the case of a strong temperature inversion. Since inversions are primarily a nighttime phenomena (3) and laboratory operation is during the day time (except for hold over on occasion) the probability of coincident containment failure and occurrence of a strong inversion was judged to be low. Additionally, regulatory guidance on calculating downwind doses does not recommend assuming inversion conditions for ground level releases. (4)

The Safety and Interlock system at the CML ensures that the critical assembly room will be sealed before any power can be supplied to increase reactivity by means of movement of control or safety rods, addition of fissile bearing solutions to experimental vessels via pumping, or movement (operation) of the movable portion of the Remote Split-Table Machine. Pressure tests are performed annually to determine that the leakage rate of the sealed room meets the containment requirements specified in the Technical Specifications for the Critical Mass Laboratory. (3)

Due to redundant operating instrumentation, automatic safety and interlock systems, and administrative procedures, it is not considered credible that a critical accident could result at the CML from any single problem, operational malfunction, or mistake, during the performance of critical

experiments. $(1,5,6)$ Experimental assemblies are brought near the critical condition for only relatively short periods of time. They are operated under specifications that: ensure that the assembly room is sealed when criticality is obtained, govern the quantity and rate of fuel addition, limit the amount of excess reactivity present in an assembly, ensure the preserice of adequate shutdown margin, ensure automatic assembly scram on power loss, and ensure the presence of a qualified senior experimenter whenever an assembly is in other than a deactivated condition. 
Depending on the experiment, it is apparent that some manual operations may be required with fuel during the performance of a critical experiment (for example, fuel elements must be positioned manually into the subcritical lattice assembly).(6) It is not feasible to close the personnel entry door with personnel in the assembly room as this door is designed to provide containment, and once secured, cannot be opened from the inside. On the other hand, the large, heavy (multi-ton) shielding door of the assembly room can only be opened from the inside, but is very slow in operation and cannot be considered as an emergency exit. Therefore, for general reasons of safety, the entry door must be open when personnel are in the assembly room.

Such operations (manual handling of fuel) are, however, permitted and considered safe for the staff involved under the applicable restrictions on critical experiments from the Technical Specifications.(7) See, also, reference four. These procedures and restrictions give adequate assurance that criticality will not occur with personnel in the Assembly Room (door open).

Apart from the critical experiment assemblies, fissionable materials are handled, transported, or stored in accordance with Criticality Safety, PNL-MA-25. (8) These procedures require criticality safety specifications governing the handling, transporting, and storing of all fissionable material. These specifications are based on the double-contingency criterion, which requires that at least two unlikely, independent, and concurrent changes must occur in process conditions before a nuclear incident is possible.

Because of the above mentioned controls, engineering and administrative, if an inadvertent criticality occurred at CML, it would probably be in the Critical Assembly Room, with the door sealed. The analysis described in the present report was performed, therefore, to evaluate the consequences of such an unspecified hypothetical criticality accident, to determine if the consequences are of significant magnitude to warrant either a revision or supplement to the current SAR. 


\section{ASSUMPTIONS AND CALCULATIONS}

The experimental assembly room at the CML is massively constructed of reinforced concrete, with gasketed doors and sealed penetrations. Ventilation ducts are sealed by gas-tight butterfly valves. The sealing capability of this room is required by CML technical specifications to prevent leakage exceeding 0.5 volume percent per hour at an overpressure of 2.0 psig. This capability must be demonstrated annually by actual pressure testing.

Due to the minimal leak rate sustainable by the experimental assembly room sealing systems, it was possible to make several conservative assumptions greatly simplifying determination of releases from the building. These assumptions resulted in the overestimation of the (small) releases within increasing estimated consequences sufficiently to indicate concern for personnel safety. Magnitude of the Critical Excursion

The critical excursion analyzed herein was assumed to produce a single burst of $1 \times 10^{18}$ fissions. A single burst was assumed because of the presence of automatic detection and shutdown mechanisms employed in experiments at the CML. The magnitude of this burst was within a factor of three of the maximum credible nuclear burst originally assumed as the design basis of the CML experimental assembly room. The original assumption was considered to be incredible in the CML, but was used to be on the conservative side.

The size of the initial burst of $1 \times 10^{18}$ fissions agrees with that postulated in the USNRC Regulatory Guide $3.35,(8)$ "Assumptions Used for Evaluating the Potential Radiological Consequences of Accidental Nuclear Criticality in a Plutonium Processing and Fuel Fabrication Plant," where it is suggested as the initial burst of an acceptable excursion for consequence evaluation. Critical burst magnitude in an experimental laboratory situation, with limited quantities of nuclear materials, would not be expected to exceed the burst magnitude which might occur in a nuclear fuel processing plant.

Production and Dispersal of Fission Products and Plutonium

Table I presents the isotopic composition and amounts of the important radionuclides assumed released to the experimental assembly room atmosphere by the critical excursion. The quantities shown in Table I represent 100 percent of the noble gases, 50 percent of the iodines, and 0.05 
percent of the plutonium and americium. The isotopic compositions agree with those listed in Table 1 of Reference 4 (which presents radionuclide quantities released by the fuel processing plant excursion discussed in Reference 4). Quantities have been adjusted to correspond to $1 \times 10^{18}$ fissions. The iodine quantities have been further adjusted to account for our assumption of 50 percent release to the room atmosphere.

Our assumption that 50 percent of the iodine is released to the room atmosphere is twice as large as that recommended in Reference 4. This large release fraction was assumed in order to accommodate any potential uncertainties in conditions between critical excursion postulated for this analysis and that postulated in Reference 8 .

The assumption of 0.05 percent release to the room atmosphere for plutonium and americium agrees with that of Reference 8 . The release is assumed to be due to aerosol formation due to solution evaporation.

Table I also presents the amounts of radionuclides escaping from the experimental assembly room and dispersed into the surrounding atmosphere. The radionuclide quantities listed in Table 1 are based on the maximum activity expected to be present within one day following the critical excursion. The maximum activity may occur several hours after the burst due to ingrowth of daughter radionuclides from precursor radionuclides. Maximizing the inventory of individual radionuclides in this way tends to maximize the potential radiological consequences.

Assumptions affecting release rates are discussed in the following sections.

Pressurization of and Leakage from the Room

After the excursion, the experimental assembly roof was assumed to be pressurized to 2 psi overpressure, despite recognition that the energy release of the excursion would not be sufficient to cause this pressurization. The maximum allowed leak rate of 0.5 percent per hour was assumed to occur, and to remain constant until the pressure decreased to one atmosphere. This would take approximately 29 hours. No further releases were assumed after pressure equilibration. Radiological decay during the 29 hours of release has been accounted for. 
No credit was assumed for plate-out of iodine or plutonium (or any other isotopes) within the room or in cracks during leakage. Meteoroiogical Conditions

The atmospheric stability during the 29-hour release period was assumed to be moderately stable. A wind speed of one meter per second was assumed for the ground level release with no change in wind direction. No credit was taken in the dispersion calculations for building wake effects, although they would cause significant dilution of released material directly downwind. The Hanford dispersion equations (9) for moderately stable conditions were used to calculate atmospheric dispersion. 
TABLE I. Radionuclide Releases

\begin{tabular}{|c|c|c|}
\hline Radionuclide & $\begin{array}{l}\text { Release to Experimental } \\
\text { Assembly Room (Ci) }\end{array}$ & $\begin{array}{l}\text { Release to } \\
\text { Atmosphere }(\mathrm{C} i)^{\star}\end{array}$ \\
\hline $83 \mathrm{Kr}$ & $1.1 \times 10^{1}$ & $1.5 \times 10^{0}$ \\
\hline $85 m_{K r}$ & $7.1 \times 10^{0}$ & $2.1 \times 10^{-1}$ \\
\hline $85 \mathrm{kr}$ & $8.1 \times 10^{-5}$ & $1.1 \times 10^{-5}$ \\
\hline${ }^{87} \mathrm{Kr}$ & $4.3 \times 10^{1}$ & $4.2 \times 10^{-1}$ \\
\hline $8 \mathrm{~B}_{\mathrm{Kr}}$ & $2.3 \times 10^{1}$ & $5.0 \times 10^{-1}$ \\
\hline $89 \mathrm{Kr}$ & $1.3 \times 10^{3}$ & $5.3 \times 10-1$ \\
\hline $131 \times e$ & $1.0 \times 10^{-2}$ & $1.3 \times 10^{-3}$ \\
\hline $133 m_{x e}$ & $2.2 \times 10^{-1}$ & $2.4 \times 10^{-2}$ \\
\hline $133 \times \mathrm{e}$ & $2.7 \times 10^{0}$ & $3.4 \times 10^{-1}$ \\
\hline $135 \mathrm{~m}_{\mathrm{Xe}}$ & $3.3 \times 10^{2}$ & $6.3 \times 10^{-1}$ \\
\hline $135 \times \mathrm{e}$ & $4.1 \times 10^{1}$ & $2.2 \times 10^{0}$ \\
\hline $137 X e$ & $4.9 \times 10^{3}$ & $2.3 \times 10^{0}$ \\
\hline $138 \times \mathrm{e}$ & $1.1 \times 10^{3}$ & $1.9 \times 100$ \\
\hline $131 \mathrm{I}$ & $5.4 \times 10^{-1}$ & $7.0 \times 10^{-2}$ \\
\hline $132 \mathrm{I}$ & $6.2 \times 10^{1}$ & $1.1 \times 10^{0}$ \\
\hline $133 \mathrm{I}$ & $8.0 \times 10^{0}$ & $7.0 \times 10^{-1}$ \\
\hline $134 \mathrm{I}$ & $2.2 \times 10^{2}$ & $1.5 \times 10^{0}$ \\
\hline 1351 & $2.3 \times 10^{1}$ & $9.7 \times 10^{-1}$ \\
\hline $238 \mathrm{Pu}$ & $5.9 \times 10^{-5}$ & $8.0 \times 10^{-6}$ \\
\hline $239 p_{U}$ & $2.7 \times 10^{-6}$ & $3.7 \times 10^{-7}$ \\
\hline $240 \mathrm{Pu}$ & $5.8 \times 10^{-6}$ & $7.9 \times 10^{-7}$ \\
\hline $241 \mathrm{Pu}$ & $1.8 \times 10^{-3}$ & $2.4 \times 10^{-4}$ \\
\hline $242 P_{U}$ & $4.3 \times 10^{-8}$ & $5.9 \times 10^{-9}$ \\
\hline $241 \mathrm{Am}$ & $2.4 \times 10^{-6}$ & $3.3 \times 10^{-7}$ \\
\hline
\end{tabular}
*alues represent the time integral of release rate over the 29 -hour
period with radiological decay prior to release. 
The dose calculations assumed no personnel movement during the 29-hour release and subsequent dispersion of the radionuclide plume. Personnel breathing rates were assumed to coorespond to "light activity" during this period.

\section{Calculational Methods}

The atmospheric and dosimetry calculations were performed within the guidelines established for Hanford related consequence analyses. (9) Radiation doses to personnel were calculated using the computer codes SUBOOSA(10) (air submersion dose) and DACRIN(11) (inhalation dose). A sumnary of data and methods used for the dose calculations is presented in Table II. 
TABLE II. Codes and Parameters Used for CML SAR Criticality Dose Calculations

Meteorological Conditions: Hanford Moderately Stable for 1-hour release

$$
\left(\sigma_{\theta} \ddot{\mathrm{u}}=0.04\right)
$$

Dispersion Model: Gaussian Bivariate Plume

$E / Q$ :

At $100 \mathrm{~m}, 7.2 \times 10^{-3} \mathrm{sec} / \mathrm{m}^{3}$; at $5000 \mathrm{~m}, 4.3 \times 10^{-5} \mathrm{sec} / \mathrm{m}^{3}$.

$\tilde{u}=1 \mathrm{~m} / \mathrm{sec}$.

Release Height: Ground level

Computer Code: DACRIN $8 / 4 / 80$

Calculated Doses: Individual dose 50-year commitment for acute exposure

Files Addressed: Organ Data Library, ORGLIB, 2/5/81

Radionuclide Library, RMDLIB, $1 / 15 / 81$

Computer Code: SUBDOSA $6 / 26 / 81$

Calculated Doses: Whole-body external using finite cloud dose model

Files Addresed: Radionuclide Library, RMDLIB, 1/15/81

Beta Energy Library, RNDBET, 6/26/81

Photon Data Library, GISLIB, 6/26/81

Dose Rate Factor Library, BIVLIB, 6/26/81 
RESIJLTS AND CONCLUSIONS

Radiation doses calculated for unevacuated personnel under the conservative assumptions discussed in the preceding section are presented in Table III. Both external and inhalation doses are presented. Radionuclides contributing to the inhalation dose and percent contributions are listed in Table IV. The contributions to the 50-year dose commitinent from all radionuclides except plutonium and americium are received within one year.

Examination of Table III shows that doses decrease with distance from the facility. The largest of the small doses (calculated for 100 meters distant from the facility) are less than 5 mrem to the whole body, less than 20 mren to bones, and less than 700 mrem to other organs (50-year dose commitment). For perspective, these may be compared to values of annual dose commitment listed in the DOE standard for protection of members of the public in uncontrolled areas. Maximum values listed for members of the public receiving maximum exposures are 500 mrem to the whole body, gonads or bone marrow, and $1500 \mathrm{mrem}$ to other organs. (1) For workers, allowed doses during normal operation are even larger, with up to 5,000 mren per year allowed to whole body and bone marrow, up to 15,000 mrem per year to other organs except bone, (1) and 30,000 mrem per year to bone. (1)

Therefore, these results demonstrate that the occurrence of a hypothetical critical excursion within the sealed experimental assembly room at the Hanford Critical Mass Laboratory presents only a very small, and completely acceptable, hazard to facilities and personnel in the area. 
TABLE III. Radiation Doses from Hypothetical CML Criticality Accident Fifty-Year Dose Commitment* (rem)

\begin{tabular}{|c|c|c|c|c|c|}
\hline \multirow[b]{2}{*}{ Distance, m } & \multirow{2}{*}{$\begin{array}{r}\text { External } \\
\text { Whole Body } \\
\end{array}$} & \multicolumn{4}{|c|}{ Inhalation } \\
\hline & & Total Body & Bone & Lungs & Thyroid \\
\hline 100 & $9.2 E-4$ & $3.9 E-3$ & $5.2 \mathrm{E}-2$ & $4.5 E-2$ & $6.2 E-1$ \\
\hline 200 & $6.2 E-4$ & $1.7 \mathrm{E}-3$ & $2.2 E-2$ & $2.0 \mathrm{E}-2$ & $2.6 \mathrm{E}-1$ \\
\hline 500 & $3.2 E-4$ & $5.4 \mathrm{E}-4$ & $7.2 \mathrm{E}-3$ & $6.3 \mathrm{E}-3$ & $8.5 E-2$ \\
\hline 1,000 & $1.8 \mathrm{E}-4$ & $2.1 E-4$ & $2.8 E-3$ & $2.4 \mathrm{E}-3$ & $3.3 E-2$ \\
\hline 2,000 & $8.5 E-5$ & $7.9 \mathrm{E}-5$ & $1.1 E-3$ & $9.2 E-4$ & $1.2 \mathrm{E}-2$ \\
\hline 5,000 & $2.5 E-5$ & $2.2 E-5$ & $3.1 E-4$ & $2.5 E-4$ & $3.5 E-3$ \\
\hline 10,000 & $8.3 E-6$ & $8.4 \mathrm{E}-6$ & $1.2 E-4$ & $9.2 E-5$ & $1.3 E-3$ \\
\hline 20,000 & $2.5 E-6$ & $3.3 E-6$ & $5.1 E-5$ & $3.5 E-5$ & $5.0 E-4$ \\
\hline
\end{tabular}

*The dose from all radionuclides except the actinides is received within the first year following release.

TABLE IV. Radionuclides Contributing to Inhalation Dose

Percent Contribution to Organ Doses

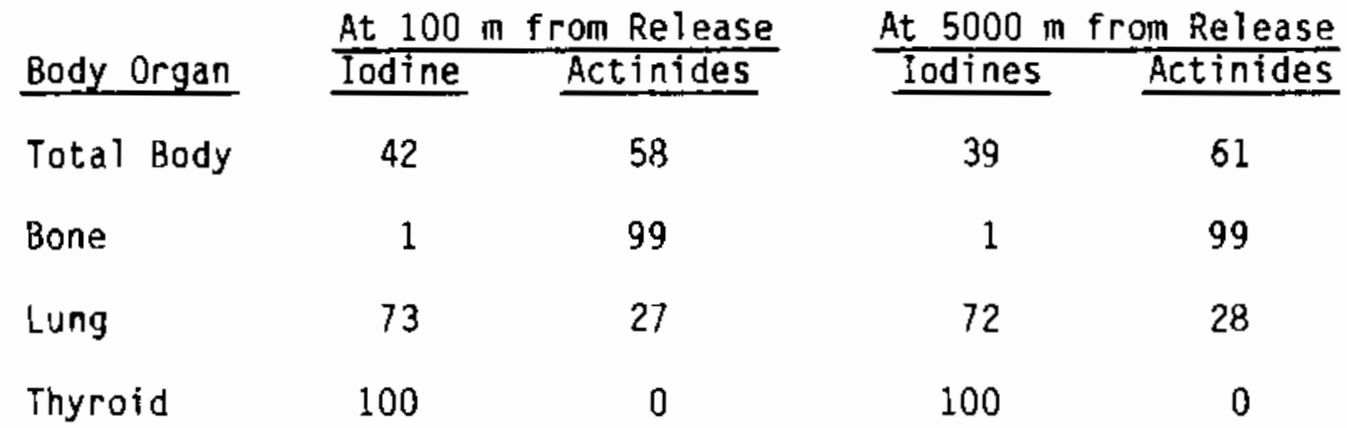




\section{REFERENCES}

1. U.S. Department of Energy. 1981. "Requirements for Radiation Protection." In DOE Order 5400, Chapter 11. Washington, D.C.

2. Reardon, H. A., E. D. Clayton, C. L. Brown, R. H. Masterson, T. J. Powell, C. R. Richey, R. B. Smith, and J. W. Healy. 1960. Hazards Summary Report for the Hanford Plutonium Critical Mass Laboratory, HW-66266. General Electric Company, Richland, Washington.

3. W. A. Stone, et al,, Climatography of the Hanford Area, BNWL-1605, Pacific Northwest Laboratory, June, 1972.

4. U.S. Nuclear Regulatory Commission. 1979. Assumptions Used for Evaluating the Potential Radiological Consequences of Accidental Nuclear Criticality in a Plutonium Processing and Fuel Fabrication Plant. Regulatory Guide 3.35. Washington, D.C.

5. C. R. Richey, et al., Hazards Summary Report for the Hanford Plutonium Critical Mass Laboratory, Supplement No. 1, The Remote Split-Table Machine, HW-66266, Supt. Rev., Generat Electric Co., RichTand, WÁ 99352 , october, 1963.

6. B. F. Gore and L. C. Davenport, Safety Analysis Report for the Hanford Critical Mass Laboratory: Supplement No. 2 - Experiments with Heterogeneous Assemblies, PNL-3749, Pacific Northwest Laboratory, Richland, WA 99325, April, 1981.

7. Energy Systems Department, Technical Specifications for the Criticality Mass Laboratory, BNWL-MA-86, (Revised Periodical1y), Pacific Northwest Laboratory, Richland, WA 99352 , May 16, 1978.

8. Dccupational and Environmental Safety Department, Criticality Safety, PNLMA-25, (Revised Periodically), Pacific Northwest Laboratory, Richland, WA 99352, November 27, 1978.

9. Napier, B. A. 1981. Standardized Input for Hanford Envi ronmental Impact Statements: Part 1, PNL-3509 Pt. 1. Pacific Northwest Laboratory, Richland, Washington.

10. Strenge, D. L., E. C. Watson, and J. R. Houston. 1975. SUBDOSA - A Computer Program for Calculating External Doses from Accidental Atmospheric Releases of Radionuctides, BNWL-B-351. Pacific Northwest Laboratory, Richland, Washington.

11. Houston, J. R., D. L. Strenge, and E. C. Watson. 1976. DACRIN - A Computer Program for Calculating Organ Dose From Acute or Chronic Radionuclide Inhalation, BNWL-B-389. Pacific Northwest Laboratory, Richtand, Washington. 
PNL -5331

UC -41

DISTRIBUTION

No. of

Copies

OFFSITE

27 DOE Technical Information Center

ONSITE

DOE Richland Operations Office

J. L. Rhoades

H. E. Ransom

35 Pacific Northwest Laboratory

G. E. Backman

J. R. Berry

S. R. Bierman

E. D. Clayton

R. M. Fleischman

B. F. Gore (3)

S. C. Hawley

J. J. Jech

H. V. Larson

R. A. Libby

R. C. Lloyd

J. Mishima (2)

C. R. Richey

E. S. Murphy

J. H. Smith

R. J. Sorenson

J. E. Spasoff

D. L. Strenge (2)

C. M. Unruh

H. H. Van Tuyl (5)

Publishing Coordination (2)

Technical Information (5) 